\title{
Magdalena Cieślak*
}

\section{Grzegorz Wiśniewski's Production of Richard III in Teatr Jaracza in Lódź-Textual Authority, the "Director's Cut", and Theatre Status}

\begin{abstract}
Grzegorz Wiśniewski’s 2012 Richard III in Teatr Jaracza in Łódź was a very successful production with critics and audiences alike. At the 2012 Gdańsk Shakespeare Festival it won the Golden Yorick, a prestigious Polish award for the best staging of a Shakespearean play in the season. Wiśniewski, a renown Polish theatre director and professor at the National Film School in Łódź, has his own way of understanding theatre, its role in culture, and Shakespeare's place in it. Wiśniewski believes in the theatre of the middle path, as he calls it, that is neither classical/conservative, nor radically avantgarde. He wants to attract wide audiences and offer them intellectual and well-balanced cultural entertainment. Without diminishing the weight of such cultural and literary icons as Shakespeare, he vivisects texts to make productions that can easily speak to a contemporary audience. This paper analyzes Wiśniewski's Richard III to show how the director manages to achieve balance between his own auteur power, the authority and complexity of Shakespeare's text, and theatre's cultural mission.
\end{abstract}

Keywords: Richard III, Grzegorz Wiśniewski, Teatr Jaracza, cultural authority, intertextuality, performance.

In The Authentic Shakespeare, Stephen Orgel claims that "Shakespeare habitually began with more than he needed," and continues to explain how in Elizabethan theatre the script on which the performance was based-the acting text of the play-was different not only from the available published texts, but also from the author's script (238). Orgel argues that Shakespeare, himself a shareholder and director in a theatre company, in his texts "offered the company a range of possibilities, and that the process of production was a collaborative one of selection as well as of realization and interpretation" (238). Seen in this way, the play text is a blueprint that takes its ultimate, if temporary, shape in production, and the playwright is not the sole author of the final shape of the play, but

* University of Łódź, Poland. 
a contributor to the joint efforts of the whole theatre company. At the same time, Elizabethan theatre, with its bare stage and minimal theatrical illusion, heavily relied on words. As famously suggested by the Prologue to Henry V_- "Admit me Chorus to this history; / Who prologue-like your humble patience pray, / Gently to hear, kindly to judge, our play," Elizabethan audiences went to hear a play. The richness of the play's verbal layer, a necessity triggered by the specificity of stage conventions, was of particular importance, as it communicated details of events, locations, time, or weather.

Contemporary theatre works differently in both respects. On the one hand, audiences definitely go to see plays. Shakespearean productions only rarely evoke the bare stage convention of early modern theatre, and present-day stage arrangements, as well as the increasing use of digital media, develop the impact of the visual layer of theatre productions. Like cinema, contemporary theatre uses various tracks of signification, the plays' language no longer being the central means of communicating meanings. On the other hand, the status of Shakespeare as a literary icon, and of his plays as canonical texts, promotes the attitude of reverence for all the words that appear in print as his. Directors and actors begin their work by confronting a piece of literature, and audiences frequently come to see a play that they have first experienced through reading, most likely in a school environment. The situation might be a little more relaxed when Shakespeare is performed not in English. Directors do not always know English well enough to read the given play in "the original," and only operate on available translations, of which there are usually more than one. As any translation is, by definition, an intervention into the source text, directors working with translations are able to negotiate the authority of Shakespeare's "letter" even in the phase of preliminary reading. While, however, translation may be seen as an element capable of corrupting, to an extent, the status of Shakespeare's words, the logophilic authority of the written text still has to be acknowledged.

In this context it is worth quoting Michael Gieleta, a UK-based theatre director of Polish origin, educated in Oxford and trained by Franco Zeffirelli. Commenting on major differences in the style of working between British and Polish theatre directors, he claims, rather critically, that Central Europe is dominated by "regietheater," which is characterised by "directorial megainterpretation" and "barbaric intervention in the text." He contrasts that approach with the British respect for the intellectual property of the author, and reverence for the authority of the text. Criticising the tendency of numerous European directors to interfere with the integrity of the text, he adds: "Editing a text is a delicate matter [...]. It takes a scalpel in the hands of a professional. A lumberjack's maniacal axe won't do." What Gieleta's comparison points to, next to a legislative issue, is the question of cultural hegemony - the authority of a canonical text, validated by the iconic status of its author. Such approach to the powers at work in theatre is particularly visible when Shakespeare is discussed 
because, as Lynda E. Boose claims, "no author or text so unequivocally locates the site of preeminent value for English speaking cultures as does Shakespeare" (707). She further observes that

\begin{abstract}
Shakespeare is a site of such competitive jostling because Shakespeare is a site of enormous cultural power. As such, he is not only a universally available but likewise a dangerously charged locale, where maneuvers for appropriation, displacement, erasure, and the institutionalization of both cultural and academic privileges are invested with a particular energy that makes the politics within this field the more recognizable and, simultaneously, perhaps the more crucial to recognize. (708)
\end{abstract}

Numerous discussions on editing, adapting, or appropriating a Shakespearean text for stage acutely show how various areas of literary and cultural authority meet. A crucial aspect in those discussions is, as Worthen puts it in Shakespeare and the Authority of Performance, "How does the Author, whose texts are consumed, transgressed, rewritten by performance, figure in the ways we account for the work of the stage?" $(1997,2)$. Presenting a case study - an analysis of Grzegorz Wiśniewski's 2012 production of Richard III in Teatr Jaracza in Łódźthis paper seeks to illustrate certain mechanisms in which the hegemony of the author/playwright is not so much subverted, but rather negotiated alongside the cultural hegemony of another author - the director - within the institutionalized domain of theatre. Assuming Barthes's distinction between work and text, Wiśniewski treats plays as texts, "the field of production rather than interpretation," as Worthen phrases it $(1997,6)$. His approach to Shakespeare is in line with Orgel's, or McGuire's, who argues that the play text is a "construct that describes that ensemble of possibilities" (qtd. in Worthen 1997, 14). Wiśniewski enjoys playing with those possibilities, and takes the liberty to open up the texts he works with, transform them, and inform them intertextually.

\title{
The "Director's Cut"
}

Wiśniewski admits that he had spent eight months reading Richard III before he started properly working on the production. ${ }^{1}$ Yet, it is not a sense of struggle with Shakespeare's play that is felt in the production, but, instead, that of

${ }^{1}$ In January 2013, Grzegorz Wiśniewski was invited by the International Shakespeare Studies Centre, University of Łódź, to give a lecture on his Richard III and on working with Shakespeare in theatre. This and a few more comments come from the lecture. For a published excerpt from the lecture see Lódź Szekspirowi w 450. rocznice urodzin, eds. Krystyna Kujawińska Courtney, Magdalena Cieślak, Agnieszka Rasmus and Monika Sosnowska. 
playing with it, and jouissance in interpreting, editing, and producing it. After months of careful study of the play, Jakub Roszkowski and Wiśniewski himself prepared an acting script that is very liberal with the play, but their editorial choices are coherent and consistent. First of all, the production does not start with the recognised and cherished soliloquy of Gloucester, but with a scene from Henry VI Part 3 showing the three brothers of York getting their hands dirty to get the throne. Richard, encouraged by both Edward and George, kills young Edward with his bare hands. This powerful moment is later repeated in the scene in which Richard brutally kills-again himself-Henry VI in the Tower. Interestingly, in this scene the character of Tyrrel is formed: the servant who was guarding Henry VI and witnessed the cold-blooded murder of the king is to become Richard's trusted assistant. Richard eventually kills him too, when Tyrrel starts to falter. The establishing scene finishes with Edward Plantagenet's speech from Henry VI Part 3, "Once more we sit in England's royal throne" (5.7). Reaching to the background story with fragments of Henry VI is frequently used to add clarity to one of the most complicated plays in Shakespeare's tetralogies. It Wiśniewski's production, however, it is not only clarity that is added with such an opening. Primarily, the play starts not with a solo performance of Richard, the chief villain and entertainer, but with joint efforts of all three York brothers, who, on the way to England's throne, are all equally guilty of murders and violence.

Very much in the vein of Jan Kott's seminal reading of Shakespeare's histories, where "every chapter opens and closes at the same point," where "history turns full circle, returning to the point of departure" (4), the production ends with Richard's coronation. He walks down the huge stairs that constitute the main element of the set, exhausted by the chain of violence and murders that led him to that point. He has one last confrontational meeting with his mother and is finally all alone. Seemingly victorious, he finishes the production with Edward's lines that opened it: "Once more we sit in England's royal throne" (Henry VI Part 3 5.7). What matters for Wiśniewski, like for Kott, is one full circle in the monarchical spiral of power-from one murder to another, from one coronation to another. What follows Richard's ascension to the throne becomes irrelevant to the production's main concerns, ${ }^{2}$ as it is made clear that the history will repeat itself, that royal power is volatile, and that each newly established king will soon be replaced by another.

Apart from the play's ending, numerous other fragments are cut: Wiśniewski has only one brother of Queen Elizabeth, Lord Rivers, instead of three; Edward and Elizabeth have one son, instead of two little boys; instead of a range of hired men and executioners, there is only Tyrrel, who merges their

2 For a more detailed discussion of the thematic focus of the production see Cieślak and Rasmus's review of Richard III (Shakespeare Bulletin 31.3). 
lines and jobs, is also given some of Buckingham's lines, and, as a result, emerges as the ultimate assassin and Richard's confidante, or "alter-ego," as Richard calls him. Those editorial cuts considerably interfere with the play text, and, by removing quite a number of characters, are in some way reductive. However, they help to clarify the plotline, and, more importantly, focus the production on certain main themes, and create more distinct characters. The production's key characters become more rounded, their problems are shown as important, and their narratives prove dramatically engaging. In this way, Wiśniewski's authority to cut the play text works, in fact, to reinforce the power of the play, and its author. Radical as the editing is, it aims at making a clearer sense of the play's intricate plotline, and eliminating the multiplicity of often confusing characters foregrounds the more compelling ones, who still remain primarily Shakespearean, not Wiśniewski's characters.

Wiśniewski not only cuts Richard III, but also imports textual additions from other sources, which is an even more daring interference with the play. For example, scene 1.3, when Rivers talks to Queen Elizabeth about the King's health, is extended: as Rivers pressures his sister to negotiate the position of Lord Protector with the King, he uses Lady Macbeth's famous "milk of human kindness" speech to Macbeth (Macbeth 1.5). These added lines seamlessly blend into their dialogue, and may remain unnoticed by many audience members, but the imported fragment is also well-known enough to be easily recognized by any keen reader of Shakespeare. Another similar addition is the scene in which Richard and Tyrrel kill Rivers. Unlike in the play, the murder takes place on stage, and they do it by taking his eyes out in a procedure borrowed from King Lear's blinding of Gloucester. Yet another addition is the onstage murder of Lady Anne, which is adapted from scene 4.2 from The Duchess of Malfi, ${ }^{3}$ in which the disguised Bosola comes to the imprisoned Duchess to make a tomb for her, and eventually strangles her. In Wiśniewski's production the executor is Tyrrel, who comes to Lady Anne, and admits he came to kill her. She appears quite composed as he gently dresses her up for the execution, and then as if cradles her to sleep, singing her a calming song before he strangles her. Seeing her death approaching, Lady Anne becomes hysterical and keeps repeating, pleadingly and with desperation, "Am not I thy duchess?" (The Duchess of Malfi 4.2).

The purpose and impact of the added fragments are different that in the case of the omissions. While the cuts are justified by the necessity to tailor the lengthy play to the time limit of the production, and effectively enhance the appeal of what is already in the source, the additions reinforce the authority of the director, who feels free to interfere with the play text as he sees fit. Importantly, Wiśniewski's choices of fragments he inserts into his production do

${ }^{3}$ Wiśniewski directed the play in 2006 in Teatr Wybrzeże. 
not stand out, but smoothly blend with the scenes to which they are added, and are used to stress the significance of the given moment of Richard III. In this way, Wiśniewski subtly evokes the authority of other texts, or even other authors, in a sense echoing the collaborative nature of early modern theatre practices. Shakespeare worked with other playwrights, did not secure author's rights to his plays, and made frequent intertextual references between his plays. Wiśniewski's interferences with Shakespeare's Richard III can be seen as following a similar logic, in which the authority of the source play, its neighbouring texts, and the production script do not fight for supremacy, but work hand in hand towards a theatrical stage product.

One more example of a textual assault, as it may be called, invokes yet another authority in performance - that of an actor. Towards the end of the production Richard, already crowned, confronts his mother. She is emotionally devastated, having witnessed not only too many deaths of those dear to her, but also the ultimate victory of the monster son she detests. A delirious shadow of former dignity, the Duchess once more tries to charge her son for his crimes, and burden him with her own misery. But he, tired and worn out, clearly wants to get her out of his way, and bursts out: "If I be so disgracious in your sight ... go ahead and puke to feel a little better." It is an interesting moment in which Shakespeare's line transforms into what must have been a rehearsal improvisation. Although it sounds odd and out of place in the Shakespearean line, it was still retained, most likely for its dramatic effect. Wiśniewski's decision to keep the improvised line highlights the role of the actor in determining the shape of the performance script, showing how it may be coauthored by actors. In this short, but quite striking, moment, the production acknowledges another aspect of the collaborative nature of a theatrical performance, which was also crucial in Shakespeare's theatrical environment. In Elizabethan theatres roles were sometimes devised and written with particular actors in mind, and the authority of the theatre company was more significant than that of the play texts that were given to the company to be performed.

In the end, in Wiśniewski's production the performance script can be seen as offering a balance between respect for the textual authority of Shakespeare's play, while acknowledging the theatrical possibilities that are inscribed in it, and the confidence and authority of the director, who allows the play to transform and evolve into a new performance text. Importantly, Wiśniewski's Richard III does not dichotomise Shakespeare's play and the director's vision of it. On the contrary, opening up to other texts and celebrating multiple efforts, it is constructed on a rhiozomatic pattern, where various authorities are interconnected and non-hierarchical.

Wiśniewski's alterations of Shakespeare's play, however, inspired some controversies. A group of students doing their BA in English literature, for example, heavily criticised the production claiming it was not Shakespeare. 
Invoking what Worthen calls "the literary valuations of a stable text," they were disappointed that the performance they saw did not "transmit Shakespearean authority" (Worthen 1997, 3). They felt the production failed to capture the essence of what Shakespeare's Richard III was for them, primarily because it lacked the play's key elements, such as: its beginning, with the famous and cherished soliloquy; other soliloquies that define Richard as the play's chief entertainer; the ending, with another famous quote from Shakespeare, "A horse! a horse! my kingdom for a horse!" (5.4); or Richard's physical deformity, to name the most obvious ones. A possible reason for such a reaction is that in the Polish educational system Shakespeare is treated as a canonical writer, taught as part of literature courses, at least one play being an obligatory text in junior high and high school curricula. Even university education positions Shakespeare within literary tradition, prioritizing the poetic aspect of his plays over the performative one. Those audience members, therefore, who were educated enough to recognize the textual changes in Richard III, had been taught to appreciate the literary, rather than theatrical, authority of Shakespeare, and, consequently, struggled with the way in which this authority was, to their minds, undermined. What they saw was a radical treatment of Shakespeare's Richard III, an assault on the text, its poetry, storyline, characters, and main themes.

Wiśniewski's production, however, follows an entirely different logic, one much closer to the specificity of theatre practices of Shakespeare's own time. As Worthen stresses, "for Shakespeare and his fellows, the principal dramatic technology was the stage and its players: plays had a very subsidiary life as printed texts" $(2008,55)$. More than that, Shakespeare lived in the period of gradual transition from oral to written culture, and wrote for a theatrical reality in which literacy, be it of his fellow actors or audiences, was not taken for granted (Worthen 2008, 56). Worthen continues to stress how handwritten manuscripts were then copied by hand for particular actors, and how "this palimpsest of writing [...] owned by the playing company" could be easily disposed of once it was no longer of use $(2008,56)$. The production script of Wiśniewski's Richard III, palimpsestic in its own way, may be seen as capturing the temporal existence of production scripts in Shakespeare's time. Prepared and collaged specifically for the given performance, it is short-lived, and immersed only in its stage existence. Moreover, even in its textual layer, the production's carefully tailored editorial choices do not challenge, but pay tribute to Shakespeare's Richard III, as well as to other works by Shakespeare his contemporaries. Consequently, the authority of Wiśniewski's performance text draws from the authority of various conflated dramatic texts and their cultural weight. Wiśniewski's strategy as the director might, then, be seen as coming from an approach similar to McGann's, according to whom "rather than [...] a derivative re-versioning of the work, one doomed to be compromised by the untenable claims of the theatre to authoritative reproduction, performance is 
definitive of the process of cultural negotiations through which works have their continued existence, their ongoing and changing life" (Worthen 1997, 15).

Before producing The Duchess of Malfi for Teatr Wybrzeże in 2006, Wiśniewski thought about it for years, and he generally believes that long preparation periods are necessary to give the director knowledge of the material and its neighbouring areas. Talking about his preparations to Richard III during the lecture for the International Shakespeare Studies Centre, Wiśniewski said: "If one examines the structure of the play, and knows other Shakespeare's texts, which feature recurrent motifs, it is possible to manipulate the original material and, at the same time, be faithful to the author's ideas." Such attitude provides him with the authority of a professional, competent in his trade and confident in his skills. Engaging with the source texts, he is at the same time armed in his directorial authority, and in the authority of other authors - such as Shakespeare - that those texts carry. The tensions between "fidelity" and "creativity" that, according to Worthen, "stalk the efforts to describe the workor art—of directing" $(1997,48)$ are not detectable in Wiśniewski's production, as the authority of Shakespeare's text is celebrated within the creative frames of the authority of the director's production.

Following Benedetti's classification, Wiśniewski's directorial mode is liberal, in that "the essential spirit of the play, transmitted but not entirely bound in the text, is happily married to the specifics of the given cast, theatre, and audience, even if this requires some adjustments in the play's form such as changes in period, language, or even structure" (Worthen 1997, 51). In a similar way in which "Shakespeare himself wrought the same changes upon antiquity [...] to recreate a universe within which the dead converse at ease with the living" (Brook qtd. in Worthen 1997, 53), Wiśniewski in his Richard III fashions Shakespeare to create a production in which Shakespeare can at ease speak to a contemporary audience.

\section{Authority of the Theatre}

Present-day theatre in itself is an interesting area in discussions of cultural authority. Writing about the making of ideology of the Royal Shakespeare Company under Hall and Nunn, Alan Sinfield notes that the company's innovative and radical programme was secured through state funding, "which was widely regarded as necessary to protect innovative work from commercial pressures" (159). In Poland, a range of selected state-subsidised theatres, such as Teatr Jaracza in Łódź, where Richard III was produced, are considered to be the bastions of legitimate culture, and are expected to fulfil a specific role. They make sure that a certain level of artistic value is retained, that certain texts are produced in certain ways to promote and sustain a certain level of cultural 
education. Such theatres, distinctly different from more populist theatres, are often considered relatively elitist or high-brow. They aim at contracting established directors, looking for recognizable actors to add to their usual cast, and offering ambitious repertoire that would be likely to do well at festivals. This combination of classicist and avant-garde notes makes them in a sense authoritative: they are cultural institutions that mark the trends and set up standards in Polish theatres, even if very recent political situation corrupts the artistic value of theatre, and tries to make it serve more blatant ideological purposes.

When dealing with a Shakespearean text, however, the cultural authority of the institution of theatre must be confronted with the iconic significance of the Bard. As Sinfield notes, theatre business of producing Shakespeare is invested with immense cultural authority, but, at the same time, there is the assumption that, regardless of how the plays change and evolve, the performance will somehow evoke the "real presence of Shakespeare" (174). Sinfield further argues that even if directors are granted a degree of inventiveness, justified by the "unevenness" of a Shakespearean text, ${ }^{4}$ the true spirit of Shakespeare is still expected to be retrieved in performance (175). Worthen, however, notes that modern theatre is a "fully nonauthoritative transmitting agent" when it comes to staging Shakespeare $(1997,12)$, an observation that can be well illustrated, and even extended, in the discussed production. Alongside the fact that modern theatre uses "texts Shakespeare never fashioned (modern editions)" (Worthen 1997, 12), one has to further acknowledge that Wiśniewski used a text that was a very modern translation into Polish. When Worthen speaks of "theatres Shakespeare never imagined," one should think not just about technology or conventions, but also of the specificity of the cultural function and authority of particular theatres in particular countries. In the context, Worthen's question whether any production can "claim to stage an authoritative work of Shakespeare" resonates as rhetorical $(1997,12)$.

Theatre, however, can also be looked at as a producing agent, rather than a transmitting one, a medium in which a text becomes a work. "If the stage constitutes the work," Worthen claims, "it constitutes a sense of 'authority' or 'fidelity' (or, for that matter, 'transgression' or 'experiment') as a rhetorical effect" $(1997,15)$. Therefore, "'Shakespeare' can speak in the theatre only in the idiom of theatre, an idiom inscribed (or not) with its own contingent rhetoric of authenticity" (Worthen 1997, 15). For Wiśniewski, the stage clearly constitutes the work, and his Richard III might pertain to an "authoritative" work of

4 Sinfield attributes this "unevenness" to factors such as "early work, collaboration, the conditions of the Elizabethan and Jacobean theatre, unsatisfactory copy texts and printers' eccentricities" (175), which are precisely the fluidities that empower theatrical flexibility. 
Shakespeare in the sense that it is authentic contemporary theatre. At the same time, the production operates within a particular type of theatre-Wiśniewski believes in the theatre of the middle path, as he calls it, that is neither classical/conservative, nor radically avant-garde. He wants to attract wide audiences, and offer them intellectual and well-balanced cultural entertainment. His Richard III, thus, can at least be seen as "an authoritative version [...], a reading which makes claim to authenticity" (Worthen 1997, 16), and, at best, as a separate work that simultaneously evokes the authorities of the author, director and theatre.

\section{The Golden Yorick}

The reception of Wiśniewski's Richard III presents an interesting valuating survey of a kind. The production was awarded the Golden Yorick at the $16^{\text {th }}$ Gdańsk Shakespeare Festival in 2012. The Golden Yorick, granted to the best Polish Shakespearean production of the given theatre season, is awarded by a jury consisting of Shakespeare academics, theatre specialists and theatre critics. Richard III received the Golden Yorick from a jury consisting of a Shakespearean scholar, two theatre studies specialists, a literary studies specialist, and a theatre critic. As the jury profile suggests, the award was a sign of appreciation of the production's theatrical quality but also, and perhaps specifically, of its way of interpreting and showcasing Shakespeare's text. Most of my Shakespearean colleagues, like myself, loved the production for its daring, but consistent and appealing, adaptation and modernisation of the play. My BA literature students, however, were very critical of the production, claiming that it was too radical in cutting the text, as well as too modern visually, and, therefore, "not really Shakespeare". From what I observed, most audience members much enjoyed the production, clearly following the narrative, appreciating the contemporary setting, and vividly responding to a few interactive moments.

Those reactions show that much depends on the background and expectations of the audience. People who go to the theatre to enjoy a cultural experience, and who treat Shakespeare as a recommendation of a quality production, are prepared to embrace the director's vision as long as it works as a piece of theatre. For them, the authority of theatre as a cultural institution, combined with the artistic authority of an icon like Shakespeare, is enough to put absolute trust in the performance that unfolds in front of them. For such audience members, the director is largely transparent, his or her role being reduced to a craftsman who, given high quality material - Shakespeare's textand high quality workshop and tools - theatre and actors - is bound to offer a high quality product. Students of English have very different expectations. Partly due to their literature-oriented training, they are not willing to assume 
a performance-oriented approach, and they revere the authority of the text as something that they feel they know. In the case of Shakespeare, they are distrustful to the very medium of theatre, treat performance as a derivative that compromises the play, and are hostile towards directorial interpretations that do not match their preferred reading of the play text. During a class discussion after the theatre outing, it took time and effort to make them see the production as a cultural product in its own right, and as having values of its own, not necessarily resulting from its relationship to the source.

Academics, both from theatre and Shakespeare studies, in turn, appreciated and valued a number of things in Wiśniewski's Richard III, the most important perhaps being the power of a well staged performance, the cultural value of quality theatre, the director's consistent and powerful vision, and informed, intelligent and original dialogue with the authority of Shakespeare and his text(s). Admittedly, such an approach to a theatrical production still attempts to make sense of it "by attributing it" to the authority of both the author-Shakespeare - and the authorised institution of stage practice - the director's work (Worthen 1997, 6). It seems, however, that the desire to validate the meaning, or success, of a production in some kind of authority, including the authority of one's own academic study, is overwhelming, at least when one is dealing with such institutionalised authorities as Shakespeare.

"What do directors do?" Worthen asks. "Do they imaginatively/slavishly translate the truth of the text into the alternative language of stage production? Or are they rival writers in the poetry of the mise-en-scène, working the materials of theatre - actors, movement, design, as well as the dramatic textinto a new original creation [...]?" $(1997,48)$. Wiśniewski is definitely a writer, skilled in a theatrical language, but he does not try to compete with the play he stages. He pays tribute to the textual authority of Shakespeare's Richard III, but, using a different theatrical idiom, he enters into an ongoing chain of intertextual dialogue with the iconic cultural authority of Shakespeare, as well as other authors whose texts he uses, with Shakespeare's literary authority, and with Shakespeare's theatrical authority. Operating within the cultural authority of the kind of theatre that he works with, he contributes his directorial expertise to create yet another Richard III, which is Shakespeare's as much as it is Wiśniewski's.

\section{WORKS CITED}

Boose, Lynda E. "The Family in Shakespeare Studies; or-Studies in the Family of Shakespeareans; or-The Politics of Politics." Renaissance Quarterly 40.4 (1987): 707-742. Print.

Cieślak, Magdalena and Agnieszka Rasmus. "King Richard III." Shakespeare Bulletin 31.3 (Fall 2013): 494-499. Print. 
Gieleta, Michał. 2013. "Michał Gieleta: Nie obraziłem się na polski teatr" (wywiad) [Michał Gieleta: I didn't take offence with the Polish theatre" (an interview)]. Wysokie Obcasy (19 April 2013). http://www.wysokieobcasy.pl/wysokie-obcasy/ 1,53668,13686392, Michal_Gieleta_Nie_obrazilem_sie_na_polski_teatr.html. (accessed 14 April 2015). Web.

Kott, Jan. Shakespeare Our Contemporary. Garden City, New York: Doubleday \& Company, Inc., 1964. Print.

Kujawińska Courtney, Krystyna, Magdalena Cieślak, Agnieszka Rasmus and Monika Sosnowska. Łódź Szekspirowi $w 450$. rocznice urodzin. Łódź: Łódzkie Towarzystwo Naukowe, Wydawnictwo Uniwersytetu Łódzkiego, 2014. Web.

Orgel, Stephen. The Authentic Shakespeare: And Other Problems of the Early Modern Stage. London and New York: Routledge, 2002. Print.

Shakespeare, William. Henry $V$. The Complete Works of William Shakespeare. MIT. Web.

Shakespeare, William. Henry VI Part 3. The Complete Works of William Shakespeare. MIT. Web.

Shakespeare, William. Macbeth. The Complete Works of William Shakespeare. MIT. Web.

Shakespeare, William. Richard III. The Complete Works of William Shakespeare. MIT. Web.

Sinfield, Alan. "Royal Shakespeare: Theatre and the Making of Ideology." Political Shakespeare. New Essays in Cultural Materialism. Eds. Jonathan Dollimore and Alan Sinfield. Manchester University Press, 1985. 158-181. Print.

Webster, John. The Duchess of Malfi. The Project Gutenberg EBook. Web.

Worthen, W.B. Shakespeare and the Authority of Performance. Cambridge University Press, 1997. Print.

Worthen, W.B. "Shakespeare 3.0: Or Text Versus Performance, the Remix." Alternative Shakespeares 3. Ed. Diana E. Henderson. London and New York: Routledge. 2008. 54-77. Print. 